\title{
FAKTOR-FAKTOR YANG MEMPENGARUHI PERMINTAAN DAGING AYAM BURAS DI PASAR TRADISIONAL KOTA MANADO
}

\author{
Chaterine I. Mamuaja, B. Rorimpandey*, E. Wantasen, S Dalie
}

Fakultas Peternakan Universitas Sam Ratulangi Manado, 95115

\begin{abstract}
ABSTRAK
Tujuan penelitian ini adalah untuk mengetahui sejauh mana pengaruh faktorfaktor harga daging ayam buras, selera dan pendapatan terhadap permintaan daging ayam buras pada konsumen pasar tradisional di Kota Manado. Metode pengambilan sampel dalam penelitian ini menggunakan metode accidental sampling. Jumlah sampel responden yang diambil secara random sebanyak 50 responden di Pasar Bersehati dan 50 responden di Pasar Pinasungkulan sehingga jumlah sampel keseluruhan sebanyak 100 Responden. Hasil penelitian menunjukkan bahwa secara bersama sama faktor-faktor harga daging ayam buras, pendapatan dan selera konsumen mempengaruhi permintaan daging ayam buras $(\mathrm{P}<0,01)$. Secara parsial faktor harga daging ayam buras dan pendapatan konsumen berpengaruh sangat nyata terhadap permintaan daging ayam buras $(\mathrm{P}<0,01)$ sedangkan selera berpengaruh nyata $(\mathrm{P}<0,10)$ terhadap permintaan daging ayam buras di pasar tradisional Kota Manado.
\end{abstract}

Kata kunci : Harga, daging ayam buras, pendapatan, selera

\footnotetext{
*Korespondensi (corresponding author)
} Email : rorimpandeyboyke@gmail.com

\begin{abstract}
FACTORS AFFECTING DEMAND FOR NATIVE CHICKEN MEAT IN TRADITIONAL MARKET MANADO CITY. The objective of this study was to know the influence of native chicken meat price, taste and consumers' income on the demand of native chicken meat in traditional market of Manado city. Accidental sampling method was use in this study. Fifty sample of consumers was randomly chosen in Bersehati market and 50 respondents taken in Pinasungkulan market. Therefore the total respondents included in this research was 100 consumers. The study showed that both overall and partially test indicated that chicken meat pice, consumers' income and consumers' appetite was significantly affecting demand for native chicken by consumers on traditional market in Manado city
\end{abstract}

Keywords: Price Native chicken meat, income, appetite

\section{PENDAHULUAN}

Subsektor peternakan merupakan bagian dari sektor pertanian yang memiliki peranan strategis dalam kehidupan perekonomian dan pembangunan sumberdaya manusia. Peranan ini dapat dilihat dari fungsi produk peternakan sebagai penyedia protein hewani yang penting bagi pertumbuhan dan 
perkembangan manusia. Oleh karena itu, produk-produk peternakan sebagai penyedia protein hewani disebut sebagai bahan "Pangan" dalam kehidupan manusia (Sudiyono et al., 2018). Daging ayam buras merupakan salah satu jenis daging yang banyak dikonsumsi oleh masyarakat baik dalam bentuk daging maupun hasil olahannya. Daging ayam buras memiliki rasa enak dan rendah kandungan lemak. Daging ayam lebih banyak dikonsumsi dibandingkan dengan daging sapi karena harga daging ayam lebih terjangkau dibandingkan daging sapi. Menurut Bima et al. (2013) permintan yang ditimbulkan oleh konsumen yang membutuhkan daging ayam buras untuk beragam kebutuhan mereka ini terdiri dari beberapa faktor yang mempengaruhinya Permintaan terhadap suatu produk peternakan dapat berupa hasil olahan maupun non olahan tergantung dari jumlah (kuantitas), harga, pendapatan maupun selera.

Pasar tradisional yang ada di Kota Manado antara lain, Pasar bersehati dan Pasar Pinasungkulan. Pasar tradisional yang ada di Manado menyediakan berbagai produk peternakan diantaranya adalah daging ayam buras.
Berdasarkan Gambar $\quad 1$ menunjukkan rata-rata konsumsi daging ayam buras perkapita pertahun di Sulawesi Utara dari tahun ke tahun mengalami peningkatan yaitu tahun 2014 sebesar 0.52 kg/kapita/tahun, Tahun 2015 naik menjadi sebesar $0.63 \mathrm{~kg} / \mathrm{kapita} / \mathrm{tahun}$, tahun 2016 sebesar 0.63 kg/kapita/tahun, dan Tahun 2017 menjadi $0.78 \mathrm{~kg} / \mathrm{kapita} /$ tahun. Perkembangan harga daging ayam buras di tingkat eceran sejak tahun 2013 hinggga tahun 2017 cenderung terus meningkat dengan rata-rata pertumbuhan sebesar $6,58 \%$ per tahun dengan harga rata-rata $\mathrm{Rp}$ 60.020,-. Peningkatan harga yang cukup signifikan mencapai $9,57 \%$ terjadi pada tahun 2013 dan 2014. Berdasarkan data tahun 2017 harga rata-rata daging ayam buras sebesar Rp 63.882,-per kg, meningkat 2,44\% dari tahun 2016 Rp62.360,-per kg (BPS, 2018) Bila di bandingkan dengan harga ayam ras pedaging, maka harga ayam buras ini jauh lebih tinggi yaitu rata-rata 2 kali dari ayam ras pedaging. Jika harga ayam ras pedaging berkisaran di harga $\mathrm{Rp} 30.000$ / $\mathrm{kg}$, maka harga ayam buras rata-rata sudah diatas $\mathrm{Rp} 60.000$ / kg . 


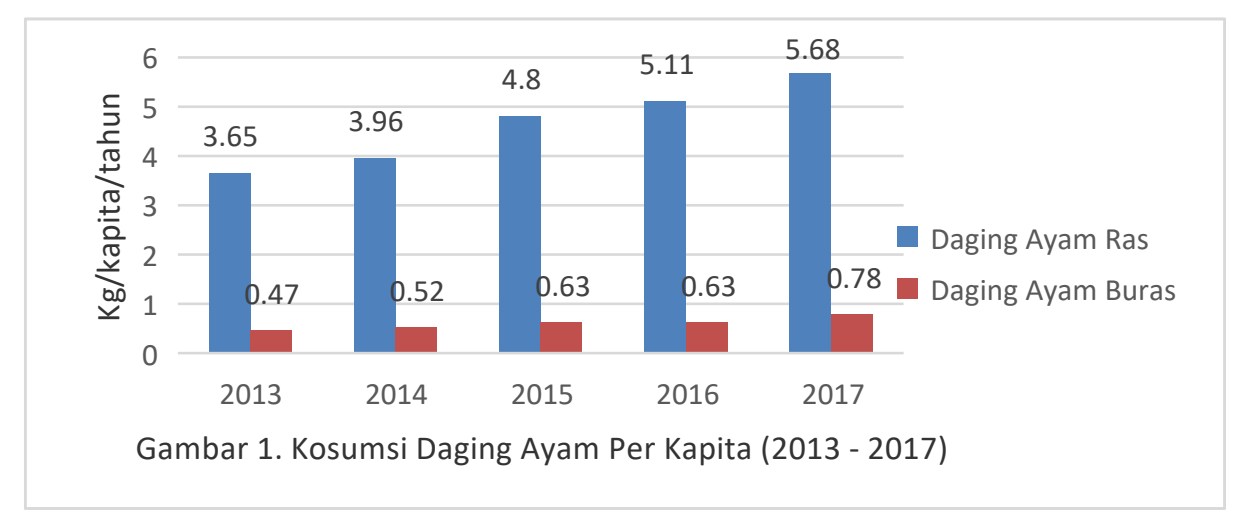

Gambar 1. Konsumsi Daging Ayam Ras Per Kapita

Tahun 2013-2017

Tercatat dalam data BPS Sulut tahun 2018 meningkatnya permintaan daging ayam buras terjadi karena adanya pergeseran pola konsumsi masyarakat dari bahan pangan sumber protein nabati ke bahan pangan sumber protein asal ternak (Siti et al., 2018). Dengan demikian meningkatnya permintaan daging ayam buras diduga dipengaruhi oleh faktor pendapatan masyarakat, selera (cita rasa) dan harga daging ayam buras. Berdasarkan latar belakang di atas, maka masalah penelitian adalah sejauh mana harga daging ayam buras, selera dan pendapatan mempengaruhi permintaan daging ayam buras di Pasar Tradisional di Kota Manado.

Tujuan penelitian ini Untuk mengetahui sejauh mana pengaruh faktorfaktor harga daging ayam buras, selera dan pendapatan terhadap permintaan daging ayam buras pada konsumen pasar tradisional di Kota Manado., sebagai bahan informasi bagi peternak maupun pedagang ayam buras tentang pengaruh faktor pendapatan, harga, selera dan pendapatan terhadap permintaan daging ayam buras di Pasar Tradisional Kota Manado.

\section{METODE PENELITIAN}

Penelitian ini telah dilaksanakan di Pasar Tradisional Kota Manado yaitu Pasar Calaca (Pasar Bersehati) dan Pasar Karombasan (Pasar Pinasungkulan), selama satu bulan, sejak 11 Juli 2019 sampai 10 Agustus 2019. Penelitian memilih Pasar Bersehati dan Pasar Pinasungkulan karna keduanya memiliki jumlah penjualan ayam buras yang cukup banyak di Kota Manado walaupun beberapa pasar tradisional lainnya menjual ayam buras namun jumlah populasinya sangat sedikit. Sumber data penelitian ini diambil pada responden sebagai konsumen daging ayam buras dan berbagai instansi terkait dengan penelitian ini. Data yang dibutuhkan dalam penelitian ini terdiri dari data primer dan data sekunder. Metode 
pengambilan sampel dalam penelitian ini menggunakan metode accidental sampling (Sugiyono, 2009) yaitu teknik penentuan sampel secara kebetulan dimana konsumen yang ditemui langsung oleh peneliti saat berbelanja di pasar tradisional yang dijadikan sampel ;penelitian. Sebanyak 50 responden di Pasar Bersehati dan 50 responden di Pasar Pinasungkulan dipilih sebagai responden sehingga jumlah sampel keseluruhan sebanyak 100 Responden. Jumlah responden tersebut diambil berdasarkan data dari Dinas Pasar Kota Manado dimana jumlkah rata rata konsumen yang berbelanja daging ayam buras di kedua pasar tersebut selama tahun 2017-2018 berjumlah 12.492 orang. Penentuan jumlah sample yang akan digunakan dalam penelitian ini menggunakan rumus (Slovin, 1960) sebagaimana tertera dibawah ini:

$$
n=\frac{N}{1+N(e)^{2}}
$$

Keterangan :

n : Jumlah Sampel

N : Jumlah Populasi

e, standar error atau persen kelonggaran $10 \%$

Maka jumlah sampelnya adalah:

$n \frac{12.492}{1+12.492(0,1)^{2}}=100$

Beberapa variabel dalam penelitian ini adalah. (1) Permintaan daging ayam buras ialah jumlah daging ayam buras yang diminta (dibeli) oleh responden di pasar tradisional (pasar bersehati dan pasar pinasungkulan) yang diukur dalam satuan kilogram per bulan (Kg/bln).

Pendapatan ialah jumlah uang yang diterima oleh kepala keluarga selama satu bulan yang diukur dalam satuan rupiah per bulan (Rp/bln). (3) Harga daging ayam buras ialah harga yang berlaku pada saat transaksi jual beli yang diukur dalam satuan rupiah per kilogram $(\mathrm{Rp} / \mathrm{Kg})$. (4) Selera konsumen ialah suatu kesukaan konsumen terhadap daging ayam bukan ras yang diukur dalam satuan nilai kualitatif dan dikonversi dengan nilai kuatitatif, yaitu : Sangat suka $=4$, Suka $=3$, Kurang suka $=2$, tidak suka $=1$.

Model analisis data yang digunakan untuk mengetahui pengaruh berbagai faktor terhadap permintaan daging ayam buras adalah model regresi linier berganda (Muhammad et al., 2013) dengan fungsi matematis sebagai berikut:

$$
\mathrm{Y}=\mathrm{b}_{0}++\mathrm{b}_{1} \mathrm{X}_{1}+\mathrm{b}_{2} \mathrm{X}_{2}+\mathrm{b}_{3} \mathrm{X}_{3}+\mathrm{e}_{\mathrm{i}}
$$

Keterangan :

$\mathrm{Y}=$ Jumlah permintaan daging ayam buras (kg/bulan)

$\mathrm{b}_{0}=$ Koefisien regresi

$\mathrm{X}_{1}=$ Harga daging ayam buras $(\mathrm{Rp} / \mathrm{kg})$

$\mathrm{X}_{2}=$ Pendapatan rata-rata $(\mathrm{Rp} / \mathrm{bln})$

$\mathrm{X}_{3}=$ Selera Konsumen (skala likert)

Untuk melakukan pengujian terhadap hipotesis yang diajukan, dilakukan uji terhadap nilai parameter 
yang diestimasi (Abdullah et al., 2014). Terdapat tiga kriteria yang umum digunakan dalam menentukan baik tidaknya sebuah model yaitu menggunakan kriteria statistik. Kriteria statistik digunakan untuk menganalisis kesesuaian model regresi yang diperoleh. Adapun beberapa pengujiannya antara lain: (a) Koefisien Determinasi $\left(\mathrm{R}^{2}\right)$. Koefisien Determinasi $\left(\mathrm{R}^{2}\right)$ digunakan untuk melihat keeratan hubungan antara semua variable bebas secara bersamasama dengan variable terikat dengan menggunakan uji goodness of fit, yaitu dengan melihat nilai $\mathrm{R}^{2}$ dimana semakin tinggi nilai $\mathrm{R}^{2}$ maka persamaan penduganya semakin baik. (Munarka et al., 2015) Analisis koefisien Determinasi digunakan untuk mengetahui persentase pengaruh secara bersama variable bebas terhadap variable terikat dalam penelitian. (b) Overall Test (Uji F). (Rochaeni et al., 2014) Uji F digunakan untuk mengetahui pengaruh variable bebas secara bersamasama terhadap variable terikat. Bila nilai $\mathrm{F}$ yang dihitung lebih besar dari nilai $\mathrm{F}$ yang terdapat, maka berarti secara keseluruhan variable bebas berpengaruh nyata terhadap variable terikat, atau dengan kata lain nilai $\mathrm{F}$ adalah signifikan. Uji F digunakan dengan rumus :

$$
\text { Fhit }=\frac{\left(R^{2}\right)}{(I-r) / n-k-l)}
$$

Keterangan:

$$
\begin{array}{ll}
\mathrm{R}^{2} & =\text { Koefisien Determinasi } \\
\mathrm{n} \quad=\text { Jumlah sampel } \\
\mathrm{k} \quad=\text { Derajat bebas pembilang } \\
\mathrm{n}-\mathrm{k}-1 \text { = Derajat bebas penyebut }
\end{array}
$$

(c) Partial Test (Uji t). (Askar et al., 2015). Uji T digunakan untuk mengetahui peran variable bebas secara parsial dikontrol oleh variable bebas lain didalam model persamaan regresi estimasi. Jika nilai statistic $\mathrm{t}$ yang dihitung lebih besar dari nilai t tabel, maka dikatakan bahwa nilai $\mathrm{t}$ tersebut signifikan.Uji statistic rumusnya sebagai berikut :

$$
\mathrm{t}_{\text {hitung }}=\frac{\beta \mathrm{i}}{\operatorname{se}(\beta i)}
$$

\section{Keterangan;}

$$
\beta \mathrm{i}=\text { koefisien regresi }
$$

$\mathrm{Se}=$ Standar Error Koefisien regresi

Kaidah pengujian: (a) Jika $t_{\text {hitung }}>t_{\text {tablet, }}$ maka tolak $\mathrm{H}_{0}$, artinya variable harga daging ayam buras, pendapatan selera konsumen berpengaruh nyata terhadap variable terikat. (b) Jika $t_{\text {hitung }}<t_{\text {tabel }}$, maka terima $\mathrm{H}_{0}$, artinya variable harga daging ayam buras, pendapatan, selera tidak berpengaruh nyata terhadap variable terikat.

\section{HASIL DAN PEMBAHASAN}

\section{Keadaan Umum Daerah Penelitian}

Kota Manado terletak di Provinsi Sulawesi Utara, berbatasan langsung dengan Kabupaten Minahasa dan Minahasa Utara. Letak astronominya 
antara $1^{\circ} 30^{\prime}-1^{\circ} 40^{\prime}$ Lintang Utara dan antara $124^{\circ}-40^{\prime}-126^{\circ} 50^{\prime}$ Bujur Timur. Luas wilayah Manado sebesar 157, 26 $\mathrm{Km}^{2}$ dan memiliki topografi tanah yang bervariasi untuk setiap kecamatan.

Secara keseluruhan, Kota Manado memiliki keadaan tanah yang berombak sebesar 37,95 persen dan dataran landai sebesar 40,16 persen dari luas wilayah. (BPS Sulut, 2017). Pasar tradisional yang terdapat di wilayah Kota Manado yang menjadi daerah atau lokasi penelitian adalah Pasar Pinasungkulan dan Pasar Bersehati.
2. karakteristik Responden

Umur Responden

Responden dalam penelitian ini adalah konsumen daging ayam kampung yang berada di pasar tradisional Kota Manado. Responden memiliki karakteristik yang beragam. (Lumenta et al, 2014; Ridha, 2017) Umur merupakan salah satu faktor pendukung untuk meningkatkan produktivitas kerja sehingga berpengaruh terhadap pembangunan suatu wilayah, baik dari aspek ekonomi, sosial dan budaya.

Tabel 1. Keadaan Umur Responden di Pasar Bersehati dan Pasar Pinasungkulan

\begin{tabular}{lrrrrrr}
\hline \multirow{2}{*}{ Umur (Th) } & \multicolumn{4}{c}{ Jumlah Responden (Org) } & \multicolumn{2}{c}{ Presentase(\%) } \\
\cline { 2 - 5 } $20-29$ & Pasar Bersehati & Pasar Pinasungkulan & Total & 0.17 \\
$30-39$ & 3 & 6.00 & 14 & 28.00 & 17 & 0.17 \\
$40-49$ & 20 & 40.00 & 10 & 20.00 & 30 & 0.3 \\
$50-59$ & 10 & 20.00 & 10 & 20.00 & 20 & 0.2 \\
$60-69$ & 3 & 6.00 & 3 & 6.00 & 6 & 0.06 \\
$70-79$ & 7 & 14.00 & 3 & 6.00 & 10 & 0.1 \\
Jumlah & 50 & 100 & 50 & 100 & 100 & 100 \\
\hline
\end{tabular}




\section{Membeli Daging Ayam Buras Dari Jenis Pekerjaan}

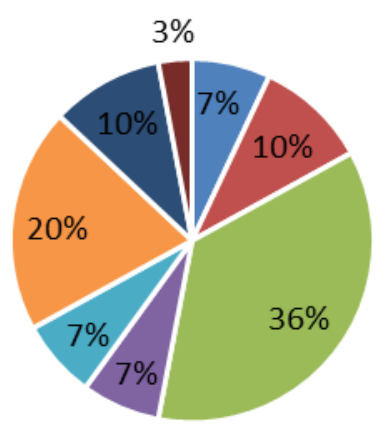

- Wartawan

- Petani

- Ibu Rumah Tangga

- Pegawai Negeri

- Pegawai Swasta

- Wiraswasta

- Pedagang

- Polisi

Gambar 3. Keadaan Responden Berdasarkan Jenis Pekerjaan di Pasar Tradisional Kota Manado.

Pekerjaan Responden

Menurut Fausayana et al., (2014) pekerjaan sangat menentukan dalam menopang perekonomian serta tingkat kesejahteraan keluarga. Jenis pekerjaan yang dimiliki oleh seseorang berpengaruh terhadap pola pembelian barang dan jasa, termasuk pembelian produk peternakan.

Gambar 2 dapat lihat bahwa terdapat bermacam-macam golongan pekerjaan yang membeli daging ayam buras di pasar tradisional di Kota Manado. Golongan konsumsi dengan jenis pekerjaan yang paling banyak yang membeli daging ayam kampung yaitu golongan pekerjaan IRT(36\%) dan golongan pekerjaan wiraswasta (20\%) dan pada golongan pekerjaan paling rendah membeli daging ayam buras yaitu golongan polisi (3\%).

Tabel 2. Hasil Analisis Regresi Faktor-faktor yang Mempengaruhi Permintaan Daging Ayam Buras Di Pasar Tradisional Di Kota Manado.

\begin{tabular}{lccc}
\hline Variabel Bebas & Konfisien Regresi & t-hitung & Prob \\
\hline Constant & 6,305 & 3,038 & $0,006^{* *}$ \\
Harga Daging Ayam Buras (HDAB) & $-0,533$ & $-3,643$ & $0,001^{* *}$ \\
Pendapatan per Kapita & 0,662 & 4,711 & $0,001^{* *}$ \\
Selera & 1,064 & 1,949 & $0,065^{*}$ \\
\hline Adjusted $\mathrm{R}^{2}=0,901$ & & \\
F-hitung $=39,233$ & & 0,000 \\
F-tabel $=2,42$ & & \\
T-tabel = 1,729 & & \\
\hline Keterangan: $* *=$ Level signifikan pada $0.01(\mathrm{P}<0.01),{ }^{*}=$ level signifikan pada $0.10(\mathrm{P}<0.1)$
\end{tabular}


Persamaan yang diperoleh dari hasil analisis Tabel 2 adalah

$\mathrm{YDAB}=6,305-0,533 \mathrm{HDAB}+0,662$

PKP + 1,064 Selera.

Berdasarkan Tabel 2 diketahui nilai koefisien deterninasi $\left(\mathrm{R}^{2}\right)$ sebesra 0,901. Koefisien (indeks) determinasi tersebut menunjukkan informasi bahwa 90,1\% perminntaan daging ayam buras dapat dijelaskan oleh variabel harga daging ayam buras, pendapatan dan selera. Ketiga variabel tersebut mempengaruhi permintaan daging ayam buras di pasar karombasan dan pasar bersehati Kota Manado.Faktor-faktor yang mempengaruhi permintaan daging ayam buras (harga daging ayam buras, pendapatan, selera) memberikan pengaruh nyata terhadap jumlah permintaan daging ayam buras. Hal ini disimpulkan berdasar nilai F-hitung yang didapatkan sebesar 39,233> F-tabel sebesar 2,42. Secara parsial, variabel harga daging ayam buras berpengaruh nyata terhadap jumlah permintaan daging ayam buras. Dapat diambil kesimpulan bahwa $\mathrm{H}_{\mathrm{o}}$ ditolak dan terima $\mathrm{H}_{1}(\mathrm{P}<0.01)$. Hal ini karena konsumen daging ayam buras mempertimbangkan harga untuk mengkonsumsi daging ayam buras, mereka mengkonsumsi karena sudah menjadi kebutuhan untuk mencukupi selera. Penelitian ini sejalan dengan hasil penelitian (Ansyari et al., 2014) mengatakan Jika harga daging ayam naik, maka masyarakat akan cenderung mengurangi konsumsi daging ayam (ceteris paribus). Secara parsial, variabel pendapatan per kapita berpengaruh nyata terhadap jumlah permintaan daging ayam buras. Dapat diambil kesimpulan bahwa $\mathrm{H}_{0}$ ditolak dan terima $\mathrm{H}_{1}(\mathrm{P}<0.01)$. Hal ini sesuai terhadap konsumen daging ayam buras dimana mereka cenderuing akan menambah atau lebih sering mengkonsumsi daging ayam buras apabila pendapatan mereka meningkat. Penelitian ini sejalan dengan hasil penelitian (Weol, 2014) mengatakan semakin tinggi pendapatan maka semakin meningkat juga jumlah permintaan telur dan daging. Secara parsial, variabel selera berpengaruh nyata terhadap jumlah perminntaan daging ayam buras $(\mathrm{P}<0,1)$. Pada umumnya hal yang membuat konsumen memiliki selera terhadap daging ayam buras karena cita rasa daging ayam buras yang enak. Sehingga hal ini dapat mempengaruhi terhadap jumlah permintaan konsumen. Penelitian ini sejalan dengan hasil penelitian (Siregar et al., 2013) mengatakan selera dapat mempengaruhi permintaan daging ayam, semakin berselera menimbulkan tingkat membeli terhadap daging ayam. 


\section{KESIMPULAN}

Faktor harga daging ayam buras, pendapatan, selera, memberikan pengaruh nyata terhadap jumlah permintaan daging ayam buras baik secara bersamaan maupun secara parsial yang dibuktikan dengan Uji F-hitung dan Uji t-hitung.

\section{DAFTAR PUSTAKA}

Abdullah, A., K Syahriadi dan M. Arif, 2014. Faktor-faktor yang mempengaruhi jumlah pembelian telur ayam ras di pasar terong Kota Makassar. Jurnal JIIP 1(2): 105124.

Ansyari. L., H. M. B. Darus dan L, Fauzia. 2014. Analisis permintaan daging ayam broiler di Sumatera Utara. Journal on Social Economic of Agriculture and Agribusiness 3(1):1-14.

Askar. B, Samsul dan Munarka, H. 2015. Faktor-faktor yang mempengaruhi permintaan daging sapi potong di Palopo. Jurnal Ekonomi Pembangunan 2 (1): 8 - 15.

BPS. 2018. Statistik Dalam Angka; Data Rata-rata Konsumsi Daging Ayam Buras Perkapita Pertahun. Manado.

Bima, H.S., B. Mozart dan Iskandarini. 2013. Faktor- faktor yang mempengaruhi perilaku konsumen dalam mengkonsumsi daging ayam kampung di Kota Medan. Journal on Social Economic of Agriculture and Agribusiness, 2(10): $1-12$.

Siti, H., N.S Lubis dan Kusuma.2018. Analisis faktor-faktor yang mempengaruhi perminntaan dan penawaran daging ayam kampung di Kota Medan. Journal on Social
Econiomic of Agriculture and Agribussiniss 9(4):1-15

Fausayana, I. 2015. Analisis faktor-faktor yang mempengaruhi permintaan telur ayam ras di Kota Kendari dan hubungannya dengan keberdayaan peternakan. Program Studi Magister Agribisnis, Universitas Halu Oleo.

Osak, R.M..F., J. Pandey, V.V.J Paneleween. I.D.R. Lumenta. 2014. Pengaruh pendapatan rumah tangga terhadap konsumsi daging di Desa Sea 1 Kecamatan Pineleng. Jurnal Zootek 34(2):10-17.K

Muhammad. H.H. Iskandirini dan H.Hasman. 2013. Analisis faktorfaktor yang mempengaruhi konsumsi daging ayam. Journal on Social Economic of Agriculture and Agribusiness 2 (2): $1-12$

Ridha, A.2017. Beberapa faktor yang mempengaruhi permintaan daging ayam broiler pada rumah tangga di Kecamatan Idi Rayeuk Kabupaten Aceh Timur. Jurnal Ilmu Ekonomi \& Studi Pembangunan 17(1):16937600

Rochaeni, S., E.Daris, dan Hanafi. 2014. Analisis faktor-faktor yang mempengaruhi permintaan tempe di Kelurahan Jurangmangu Timur Pondok Aren Tangerang Selatan. Jurnal Agribisnis 8 (1): 1 - 14

Siregar. M. F. A dan H. H. Iskandarini. 2013. Analisis faktor-faktor yang mempengaruhi konsumsi daging ayam. Journal on Social Economic of Agriculture and Agribusiness 2 (2):1- 12 .

Slovin.1960. Populasi dan Sampel Penelitian. Erlangga. Jakarta 
Sugiyono. 2009. Metode Penelitian Pendidikan Pendekatan Kuantitatif Kualitatif. Alfabeta.Bandung.

Sudiyono., H.S Purnomo dan Amelia. 2018. Faktor-faktor yang mempengaruhi permintaan daging ayam kampung di pasar tradisional Kota Surakata. Jurnal Sain Peternakan 16 (1): 23-29.
Weol, E. F., B. Rorimpandey. G.D Lenzum.dan E.K.M Endoh. 2014. Analisis pengaruh pendapatan rumah tangga terhadap konsumsi daging dan telur di Kecamatan Suluun Tareran Kabupaten Minahasa Selatan. Jurnal Zootek, 34(1): 37-47. 